\title{
Online Appendix Information Asymmetries in Consumer Credit Markets: Evidence from Payday Lending
}

\author{
Will Dobbie Paige Marta Skiba \\ Harvard University Vanderbilt University
}

March 2013 


\begin{tabular}{ccc}
\multicolumn{3}{c}{$\begin{array}{c}\text { Online Appendix Table } 1 \\
\text { Difference-in-Difference Estimates of the } \\
\text { Effect of Loan Amount on Default }\end{array}$} \\
\hline \hline \multirow{2}{*}{ Loan Amount } & $(1)$ & $(2)$ \\
\cline { 2 - 3 } Age & $-0.036^{*}$ & $-0.035^{*}$ \\
& $(0.021)$ & $(0.022)$ \\
Black & $-0.452^{* * *}$ \\
& $(0.033)$ \\
Male & -1.120 \\
& $(1.834)$ \\
Credit Score & 0.800 \\
& & $(1.551)$ \\
Checkings & $-0.040^{* * *}$ \\
& & $(0.004)$ \\
Home Owner & 0.000 \\
& & $(0.002)$ \\
Direct Deposit & -1.042 \\
& & $(1.617)$ \\
Garnishment & -0.322 \\
& & $(1.421)$ \\
\hline Observations & 8.535 \\
\hline \hline
\end{tabular}

Notes: This table reports difference-in-difference estimates of the impact of loan amount on default. The sample consists of first-time payday-loan borrowers living in states offering payday loans in $\$ 50$ increments who are paid biweekly or semimonthly earning between $\$ 100$ and $\$ 1100$ every two weeks. We instrument for loan size using a linear trend in income interacted with an indicator variable for living in Tennessee and being eligible for a \$200 loan. All regressions control for month-, year-, and state-of-loan effects. The dependent variable is an indicator for bouncing a check on the first loan. Coefficients and robust standard errors are multiplied by $100 .{ }^{* * *}=$ significant at 1 percent level, $* *=$ significant at 5 percent level, $*=$ significant at 10 percent level. 
Online Appendix Table 2

OLS Estimates of Borrower Characteristics on Loan Choice

\begin{tabular}{|c|c|c|c|c|c|c|}
\hline & & RD Sample & & & RK Sample & \\
\hline & (1) & (2) & (3) & (4) & (5) & (6) \\
\hline Pay & $-0.074^{* * *}$ & $-0.076^{* * *}$ & $0.020^{* *}$ & $-0.006^{* * *}$ & $-0.006^{* * *}$ & $0.016^{* * *}$ \\
\hline & $(0.002)$ & $(0.002)$ & $(0.010)$ & $(0.000)$ & $(0.000)$ & $(0.000)$ \\
\hline Age & & $0.152^{* * *}$ & $0.156^{* * *}$ & & $0.026^{* *}$ & $0.031^{* * *}$ \\
\hline & & $(0.038)$ & $(0.038)$ & & $(0.011)$ & $(0.011)$ \\
\hline Black & & $-8.281^{* * *}$ & $-8.558^{* * *}$ & & $-0.838^{*}$ & -0.718 \\
\hline & & $(2.968)$ & $(2.985)$ & & $(0.472)$ & $(0.467)$ \\
\hline Male & & 0.894 & 1.238 & & $1.187^{* *}$ & $1.882^{* * *}$ \\
\hline & & $(2.739)$ & $(2.707)$ & & $(0.491)$ & $(0.487)$ \\
\hline Credit Score & & -0.002 & -0.003 & & $-0.005^{* * *}$ & $-0.002^{*}$ \\
\hline & & $(0.006)$ & $(0.006)$ & & $(0.001)$ & $(0.001)$ \\
\hline Checkings & & $0.003^{*}$ & 0.003 & & $0.001^{* * *}$ & $0.002^{* * *}$ \\
\hline & & $(0.002)$ & $(0.002)$ & & $(0.000)$ & $(0.000)$ \\
\hline Home Owner & & 1.011 & 0.885 & & $4.191^{* * *}$ & $4.371^{* * *}$ \\
\hline & & $(2.915)$ & $(2.914)$ & & $(0.549)$ & $(0.545)$ \\
\hline Direct Deposit & & -0.167 & -1.047 & & $-2.260^{* * *}$ & $-0.748^{* *}$ \\
\hline & & $(2.183)$ & $(2.165)$ & & $(0.383)$ & $(0.381)$ \\
\hline Garnishment & & -0.594 & -0.958 & & -0.258 & -0.641 \\
\hline & & $(7.422)$ & $(7.368)$ & & $(1.531)$ & $(1.516)$ \\
\hline Loan Eligibility & & & $-0.202^{* * *}$ & & & $-0.094^{* * *}$ \\
\hline & & & $(0.021)$ & & & $(0.002)$ \\
\hline $\mathrm{R}^{2}$ & 0.242 & 0.246 & 0.254 & 0.166 & 0.168 & 0.182 \\
\hline Observations & 9,473 & 9,473 & 9,473 & 130,025 & 130,025 & 130,025 \\
\hline
\end{tabular}

Notes: This table reports OLS estimates of the cross-sectional correlation between borrower characteristics and loan choice. The regression discontinuity (RD) sample consists of first-time paydayloan borrowers living in states offering payday loans in $\$ 50$ increments who are paid biweekly or semimonthly earning between $\$ 100$ and $\$ 1100$ every two weeks. The regression kink (RK) sample consists of first-time payday-loan borrowers living in states offering payday loans in $\$ 1$ or $\$ 10$ increments who are paid biweekly or semimonthly earning more than $\$ 100$ and within $\$ 1000$ of a kink point. The dependent variable is an indicator for choosing the largest loan the borrower is eligible for. All regressions control for month-, year-, and state-of-loan effects. Coefficients and robust standard errors are multiplied by $100 . * * *=$ significant at 1 percent level, $* *=$ significant at 5 percent level, $*=$ significant at 10 percent level. 


\section{Online Appendix Table 3}

Regression Discontinuity Tests of Quasi-Random Assignment

\begin{tabular}{|c|c|c|c|}
\hline & Polynomial & Spline & Linear \\
\hline Characteristics & (1) & (2) & (3) \\
\hline \multirow[t]{3}{*}{ Age } & 0.204 & 0.260 & 0.021 \\
\hline & $(0.295)$ & $(0.289)$ & $(0.528)$ \\
\hline & 9443 & 9443 & 9443 \\
\hline \multirow[t]{3}{*}{ Black } & 0.012 & 0.007 & 0.021 \\
\hline & $(0.025)$ & $(0.027)$ & $(0.043)$ \\
\hline & 1316 & 1316 & 1316 \\
\hline \multirow[t]{3}{*}{ Male } & 0.005 & 0.009 & -0.038 \\
\hline & $(0.027)$ & $(0.028)$ & $(0.044)$ \\
\hline & 1316 & 1316 & 1316 \\
\hline \multirow[t]{3}{*}{ Credit Score } & -2.537 & -4.855 & -18.322 \\
\hline & $(7.281)$ & $(7.357)$ & $(13.882)$ \\
\hline & 2165 & 2165 & 2165 \\
\hline \multirow[t]{3}{*}{ Checkings } & 4.954 & 6.268 & -17.160 \\
\hline & $(16.305)$ & $(16.800)$ & $(32.300)$ \\
\hline & 2274 & 2274 & 2274 \\
\hline \multirow[t]{3}{*}{ Home Owner } & 0.007 & 0.004 & -0.042 \\
\hline & $(0.027)$ & $(0.028)$ & $(0.047)$ \\
\hline & 1160 & 1160 & 1160 \\
\hline \multirow[t]{3}{*}{ Direct Deposit } & 0.000 & 0.004 & -0.006 \\
\hline & $(0.018)$ & $(0.018)$ & $(0.032)$ \\
\hline & 2350 & 2350 & 2350 \\
\hline \multirow[t]{3}{*}{ Garnishment } & -0.009 & -0.009 & -0.006 \\
\hline & $(0.010)$ & $(0.010)$ & $(0.015)$ \\
\hline & 1160 & 1160 & 1160 \\
\hline \multicolumn{4}{|l|}{ Density Test } \\
\hline \multirow[t]{3}{*}{ Nbr. of Borrowers } & 2.208 & 2.309 & -28.313 \\
\hline & $(1.929)$ & $(1.857)$ & $(24.044)$ \\
\hline & 100 & 100 & 10 \\
\hline
\end{tabular}

Notes: This table reports tests of quasi-random assignment in our regression discontinuity design. The sample consists of first-time payday-loan borrowers living in states offering payday loans in $\$ 50$ increments who are paid biweekly or semimonthly earning between $\$ 100$ and $\$ 1100$ every two weeks. Column 1 controls for a seventh-order polynomial in net pay. Column 2 controls for a linear spline in net pay. Column 3 stacks data from each cutoff and controls for net pay using a linear regression interacted with the loan cutoff. Loan eligibility is the maximum loan size an individual is eligible for. All regressions control for month-, year-, and state-of-loan effects. Standard errors are clustered by pay. Number of borrowers is defined using $\$ 10$ bins in pay. See text for additional details. $* * *=$ significant at 1 percent level, $* *=$ significant at 5 percent level, $*=$ significant at 10 percent level. 


\begin{tabular}{|c|c|c|}
\hline \multicolumn{3}{|c|}{$\begin{array}{c}\text { Appenidx Table } 4 \\
\text { Regression Kink Tests of Quasi-Random Assignment } \\
\end{array}$} \\
\hline \multirow{6}{*}{$\begin{array}{l}\text { Characteristics } \\
\text { Age }\end{array}$} & $\$ 300$ & $\$ 500$ \\
\hline & Cutoff & Cutoff \\
\hline & (1) & $(2)$ \\
\hline & $-0.209^{*}$ & $-0.142^{* * *}$ \\
\hline & $(0.112)$ & $(0.036)$ \\
\hline & 33,164 & 96,631 \\
\hline \multirow[t]{3}{*}{ Black } & - & $-0.013^{* * *}$ \\
\hline & & $(0.003)$ \\
\hline & & 40,878 \\
\hline \multirow[t]{3}{*}{ Male } & - & $0.006^{* *}$ \\
\hline & & $(0.003)$ \\
\hline & & 40,878 \\
\hline \multirow[t]{3}{*}{ Credit Score } & - & $-1.229^{*}$ \\
\hline & & $(0.738)$ \\
\hline & & 91,261 \\
\hline \multirow[t]{3}{*}{ Checkings } & - & 0.540 \\
\hline & & $(2.421)$ \\
\hline & & 89,844 \\
\hline \multirow[t]{3}{*}{ Home Owner } & - & $0.008^{* *}$ \\
\hline & & $(0.003)$ \\
\hline & & 34,133 \\
\hline \multirow[t]{3}{*}{ Direct Deposit } & - & $-0.025^{* * *}$ \\
\hline & & $(0.002)$ \\
\hline & & 91,790 \\
\hline \multirow[t]{3}{*}{ Garnishment } & - & $0.002^{*}$ \\
\hline & & $(0.001)$ \\
\hline & & 34,133 \\
\hline \multicolumn{3}{|l|}{ Density Test } \\
\hline \multirow[t]{3}{*}{ Nbr. of Borrowers } & -4.754 & -1.546 \\
\hline & $(5.528)$ & $(4.490)$ \\
\hline & 61 & 77 \\
\hline
\end{tabular}

Notes: This table reports tests of quasi-random assignment in our regression kink design. The sample consists of first-time payday-loan borrowers living in states offering payday loans in $\$ 1$ or $\$ 10$ increments who are paid biweekly or semimonthly earning more than $\$ 100$ and within $\$ 1000$ of a kink point. Loan cutoff is an indicator for eligibility for the largest loan available in a state. All regressions using baseline characteristics control pay and month-, year-, and state-ofloan effects. Standard errors are clustered by pay. Number of borrowers is defined using \$10 bins in pay. Regressions using the number of borrowers control for a seventh-order polynomial in pay interacted with the loan cutoff. See text for additional details. $* * *=$ significant at 1 percent level, $* *=$ significant at 5 percent level, $*=$ significant at 10 percent level. 
Online Appendix Table 5

Regression Discontinuity Falsification Test of the First Stage

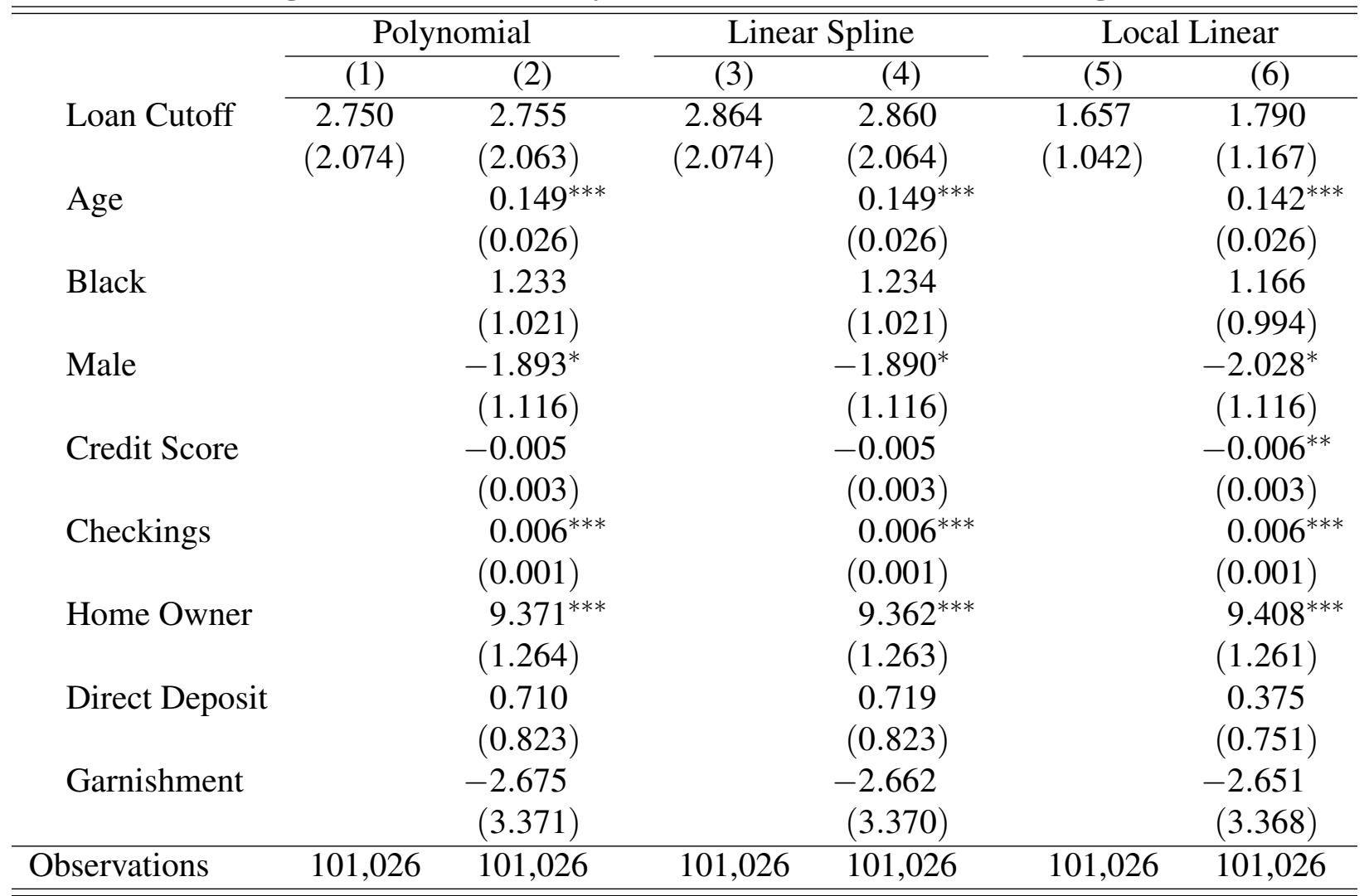

Notes: This table reports regression discontinuity first-stage estimates in a sample of states where no effect is expected. The sample consists of first-time payday-loan borrowers living in states offering payday loans in $\$ 1$ or $\$ 10$ increments who are paid biweekly or semimonthly earning between $\$ 100$ and $\$ 1100$ every two weeks. Columns 1-2 control for a seventh-order polynomial in net pay. Columns 3-4 control for a linear spline in net pay. Columns 5-6 stack data from each cutoff and control for net pay using a linear regression interacted with the loan cutoff. The dependent variable is the dollar amount of the borrower's first loan. Loan eligibility is the maximum loan size an individual is eligible for. All regressions control for month-, year-, and state-of-loan effects. Columns 5 and 6 also control for cutoff fixed effects. Standard errors are clustered by pay. $* * *=$ significant at 1 percent level, ${ }^{* *}=$ significant at 5 percent level, ${ }^{*}=$ significant at 10 percent level. 
Online Appendix Table 6

Regression Discontinuity Falsification Test of the Main Results

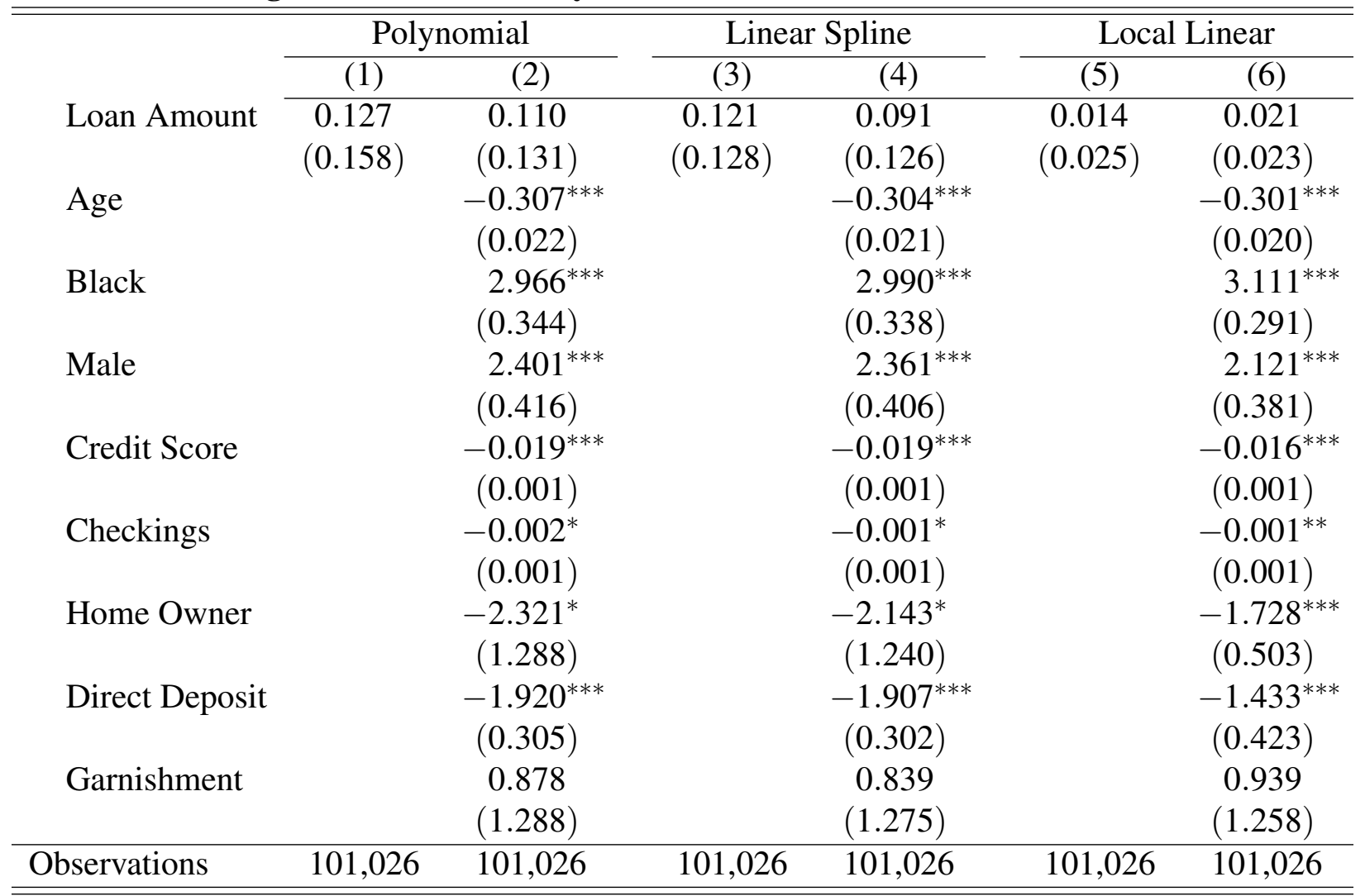

Notes: This table reports regression discontinuity estimates of loan amount on default in a sample of states where no effect is expected. The sample consists of first-time payday-loan borrowers living in states offering payday loans in $\$ 1$ or $\$ 10$ increments who are paid biweekly or semimonthly earning between $\$ 100$ and $\$ 1100$ every two weeks. Columns 1-2 control for a seventh-order polynomial in net pay. Columns 3-4 control for a linear spline in net pay. Columns 5-6 stack data from each cutoff and control for net pay using a linear regression interacted with the loan cutoff. The dependent variable is an indicator for bouncing a check on the first loan. All regressions instrument for loan amount using loan eligibility and control for month-, year-, and state-of-loan effects. Columns 5 and 6 also control for cutoff fixed effects. Standard errors are clustered by pay. Coefficients and standard errors are multiplied by $100 . * * *=$ significant at 1 percent level, $* *=$ significant at 5 percent level, $*$ = significant at 10 percent level. 


\section{Online Appendix Figure 1A \\ Regression Discontinuity Tests of Quasi-Random Assignment Baseline Characteristics}

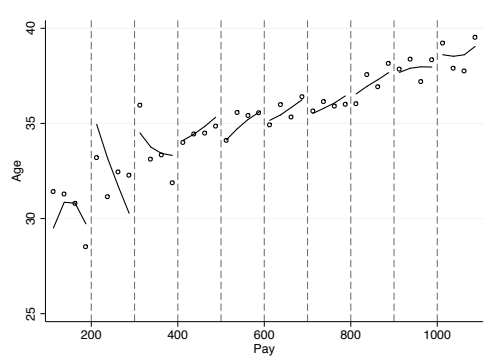

A. Polynomial

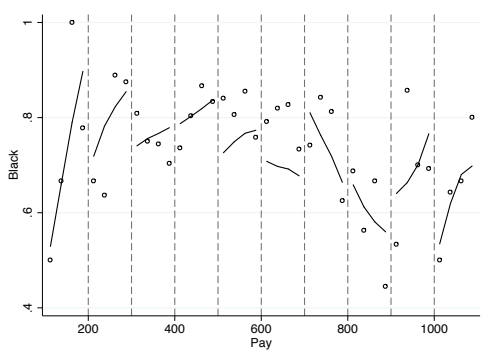

A. Polynomial

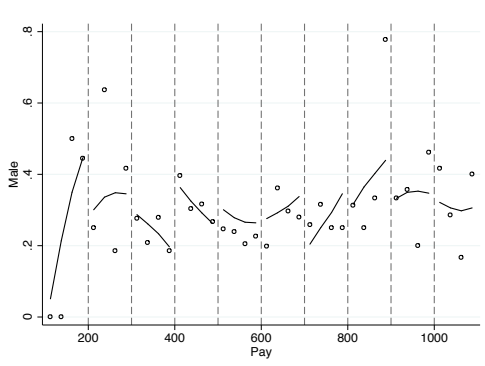

A. Polynomial

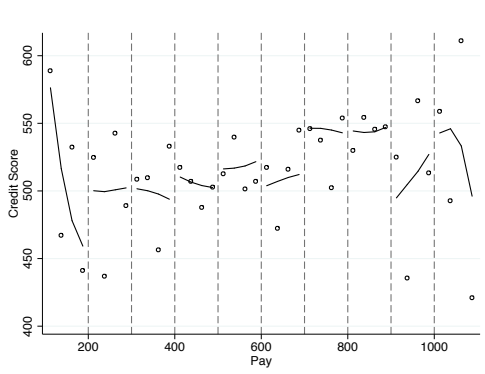

A. Polynomial

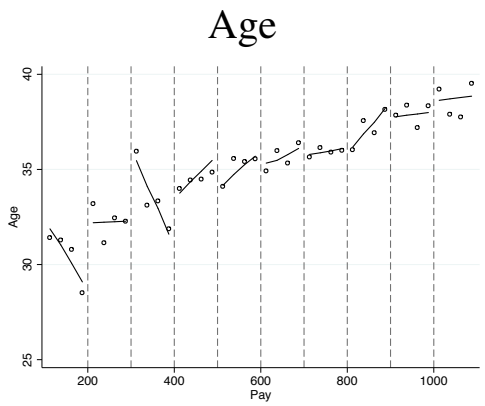

B. Linear Spline

Fraction Black

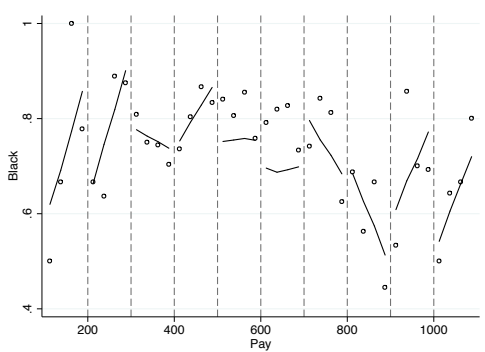

B. Linear Spline

Fraction Male

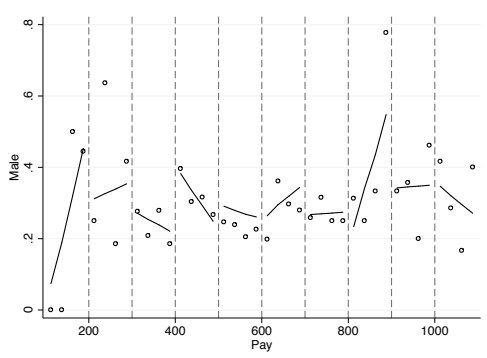

B. Linear Spline

\section{Credit Score}

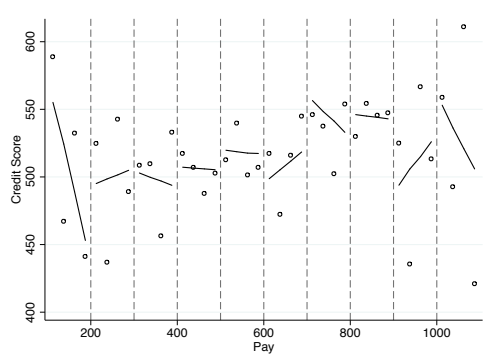

B. Linear Spline

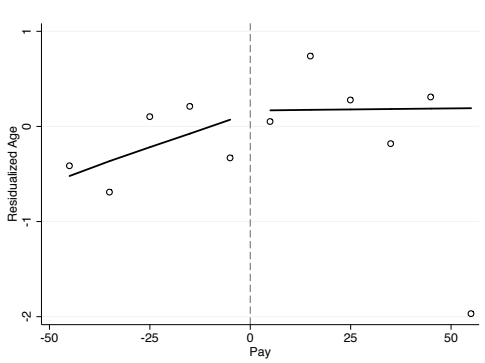

C. Local Linear

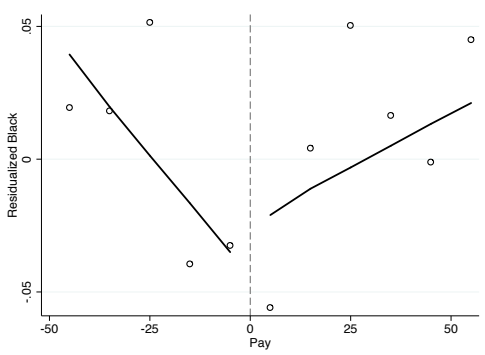

C. Local Linear

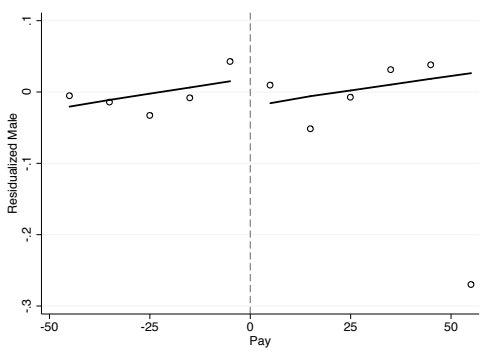

C. Local Linear

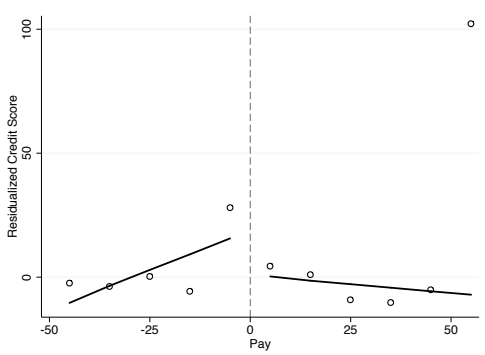

C. Local Linear 
Checking Balance

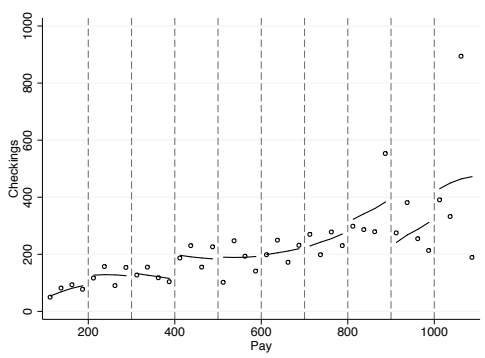

A. Polynomial

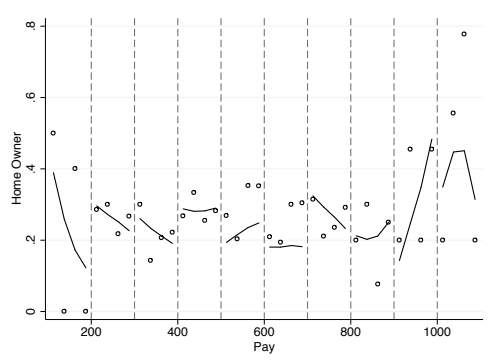

A. Polynomial

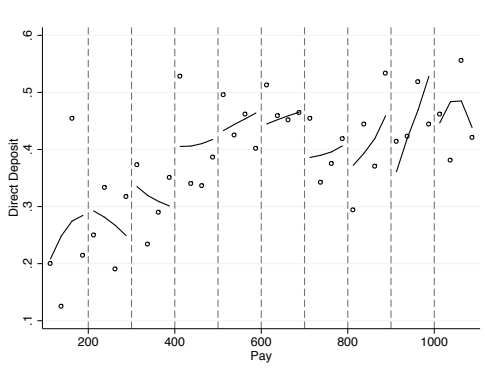

A. Polynomial

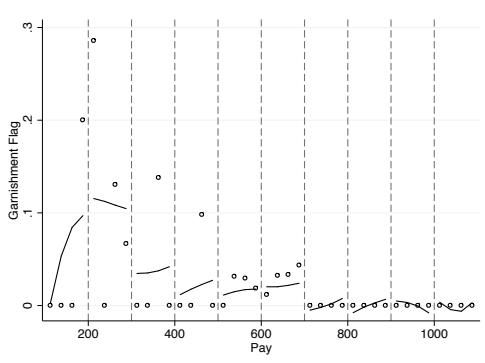

A. Polynomial

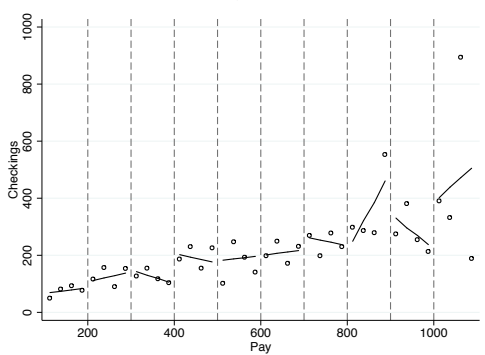

B. Linear Spline

Home Ownership

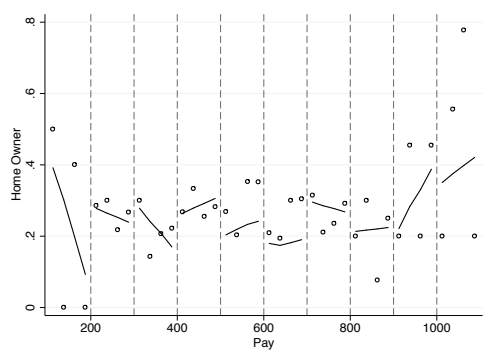

B. Linear Spline

Direct Deposit

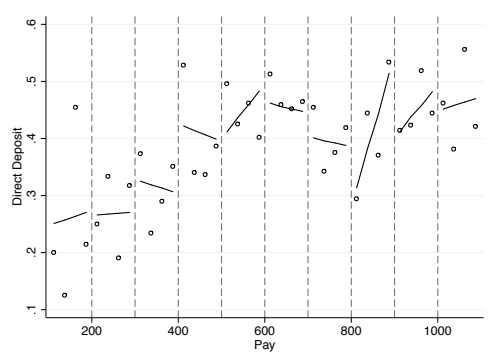

B. Linear Spline

Garnishment

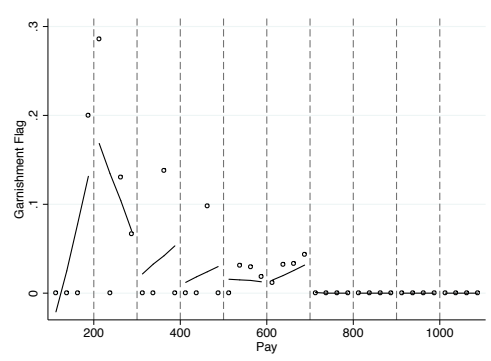

B. Linear Spline

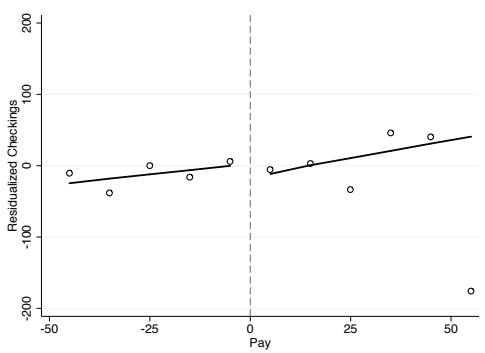

C. Local Linear

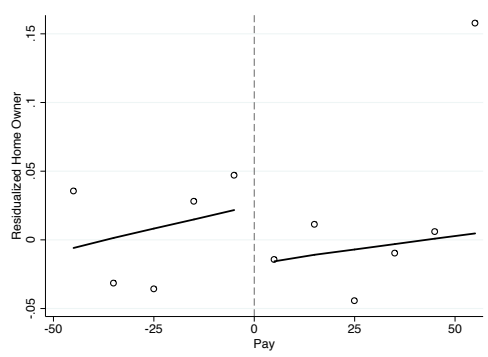

C. Local Linear

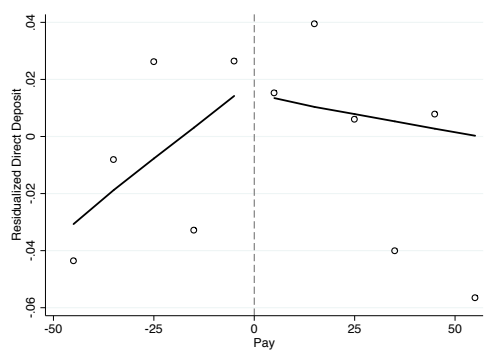

C. Local Linear

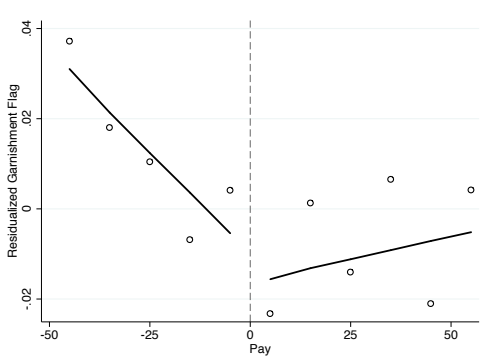

C. Local Linear 
Notes: These figures plot baseline characteristics and biweekly pay for first-time payday borrowers in our regression discontinuity sample. The sample consists of borrowers living in states offering payday loans in $\$ 50$ increments who are paid biweekly or semimonthly between $\$ 100$ and $\$ 1100$. The smoothed line in the first column of figures controls for a seventh-order polynomial in net pay. The second column controls for a linear spline in net pay. The third column stacks data from each cutoff and controls for net pay using a linear regression and a linear regression interacted with the loan cutoff. See text for additional details. 


\section{Online Appendix Figure 1B \\ Regression Discontinuity Tests of Quasi-Random Assignment Number of Observations}

A. Polynomial

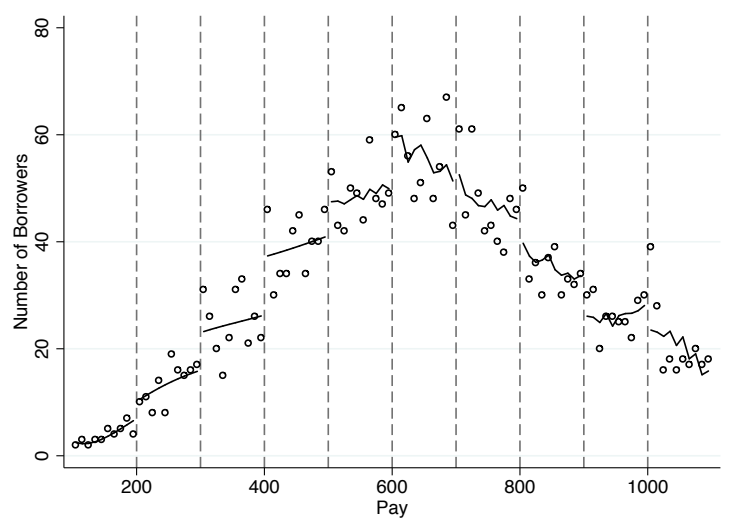

B. Linear Spline

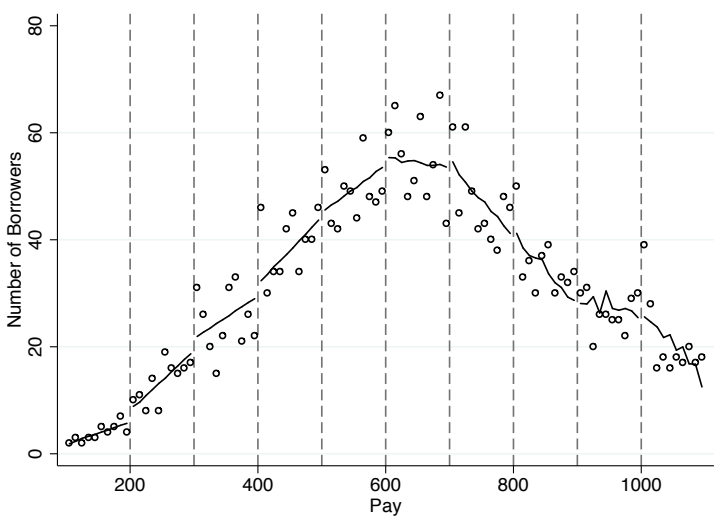

C. Local Linear

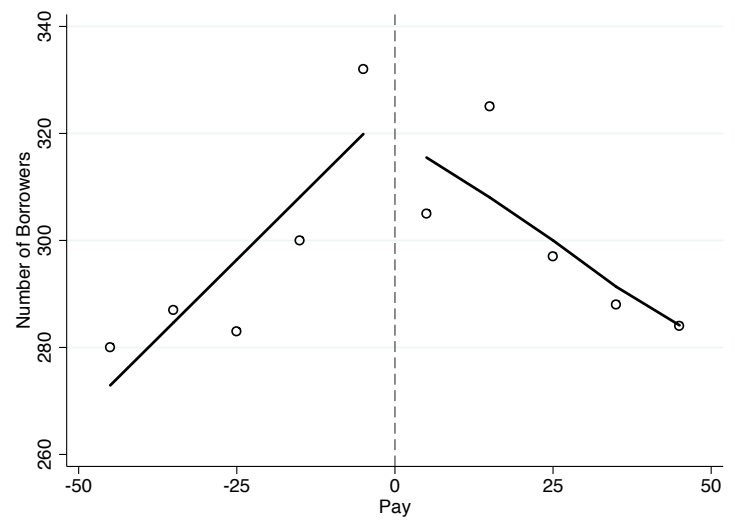

Notes: These figures plot the number of borrowers and biweekly pay for first-time payday borrowers in our regression discontinuity sample. The sample consists of borrowers living in states offering payday loans in $\$ 50$ increments who are paid biweekly or semimonthly between $\$ 100$ and $\$ 1100$. The smoothed line in the first figure controls for a seventh-order polynomial in net pay. The second figure controls for a linear spline in net pay. The third figure stacks data from each cutoff and controls for net pay using a linear regression and a linear regression interacted with the loan cutoff. See text for additional details. 


\section{Online Appendix Figure 2A \\ Regression Kink Results \\ Test of Quasi-Random Assignment}

Fraction Black

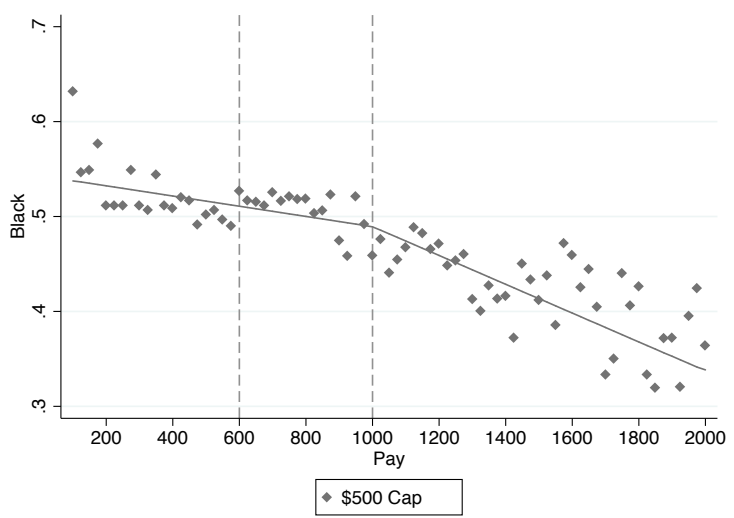

Credit Score

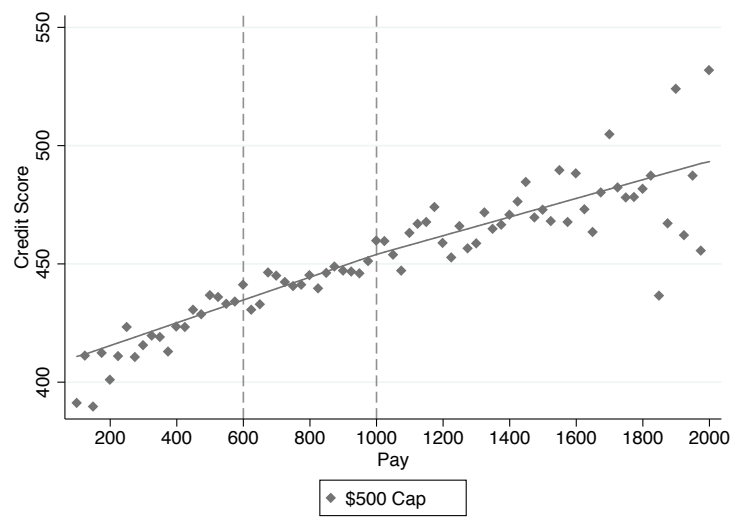

Home Ownership

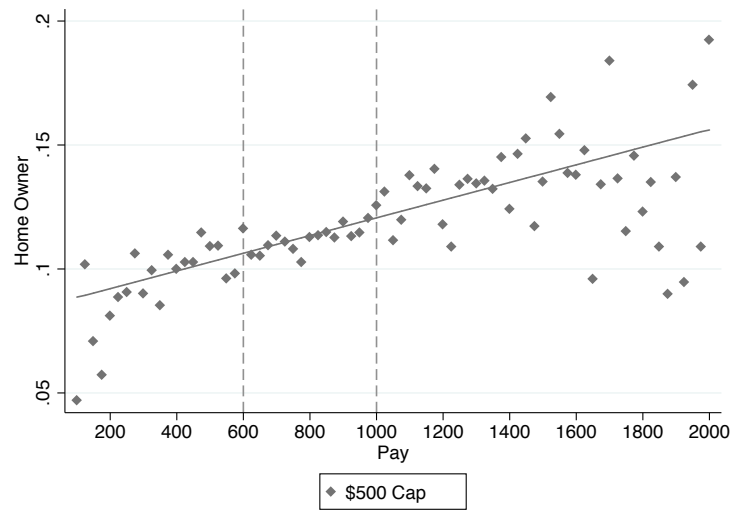

Fraction Male

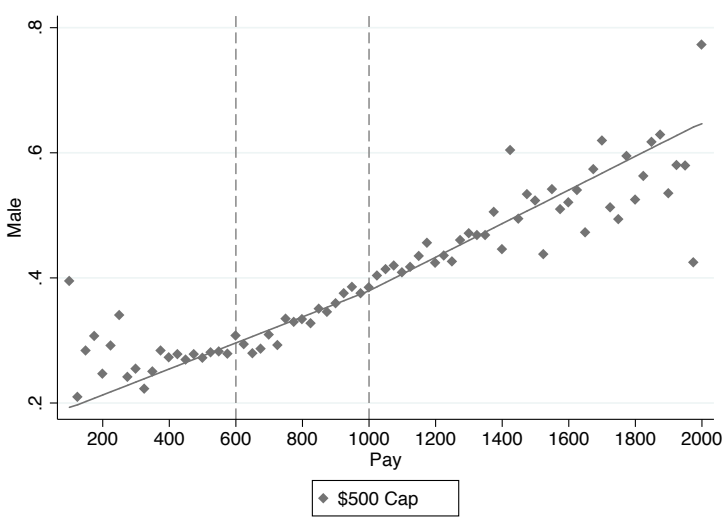

Checking Balance

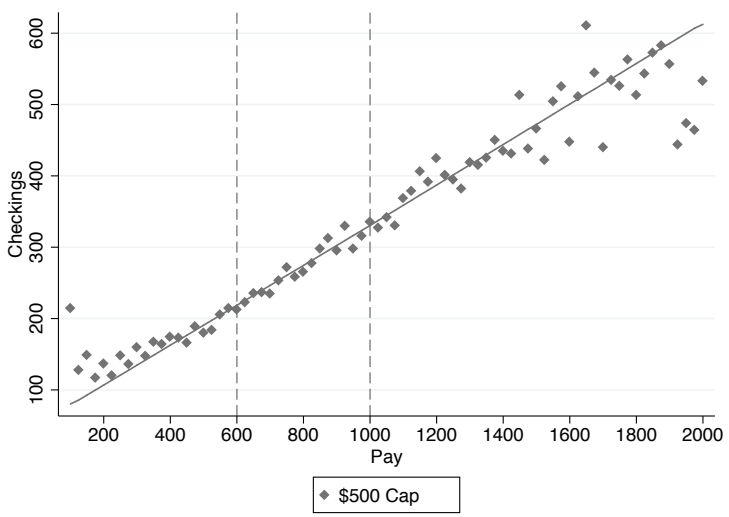

Direct Deposit

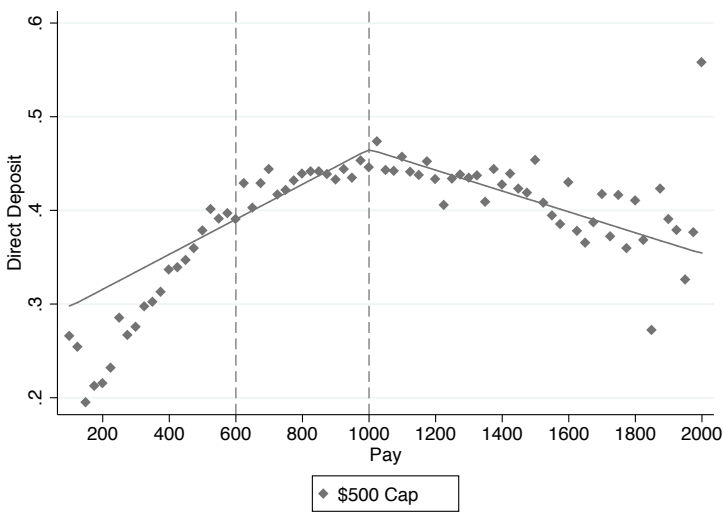



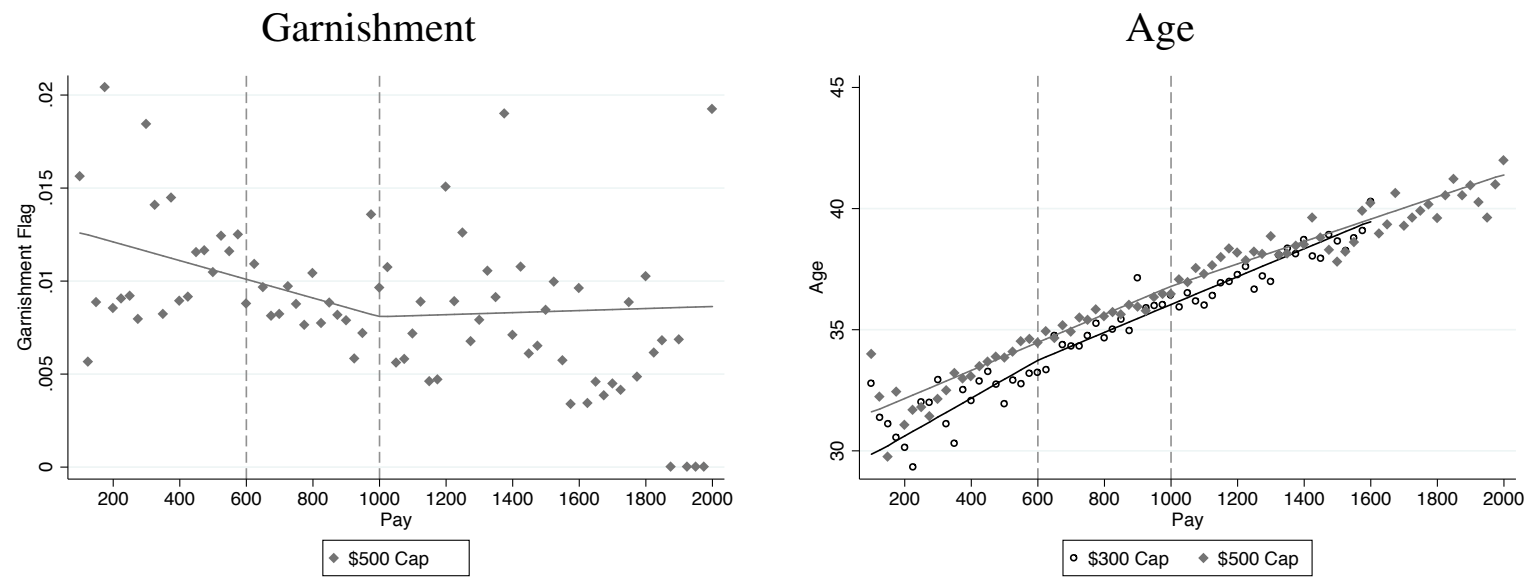

Notes: These figures plots average baseline characteristics and biweekly pay for first-time payday borrowers in our regression kink sample. The sample consists of borrowers living in states offering payday loans in $\$ 1$ or $\$ 10$ increments who are paid biweekly or semimonthly and earning more than $\$ 100$ and within $\$ 1000$ of a kink point. The smoothed line controls for pay interacted with being eligible for the maximum loan size in a state. Age is the only baseline characteristic available for states with a $\$ 300$ cap. See text for additional details. 


\section{Online Appendix Figure 2B \\ Regression Kink Results \\ Test of Quasi-Random Assignment}

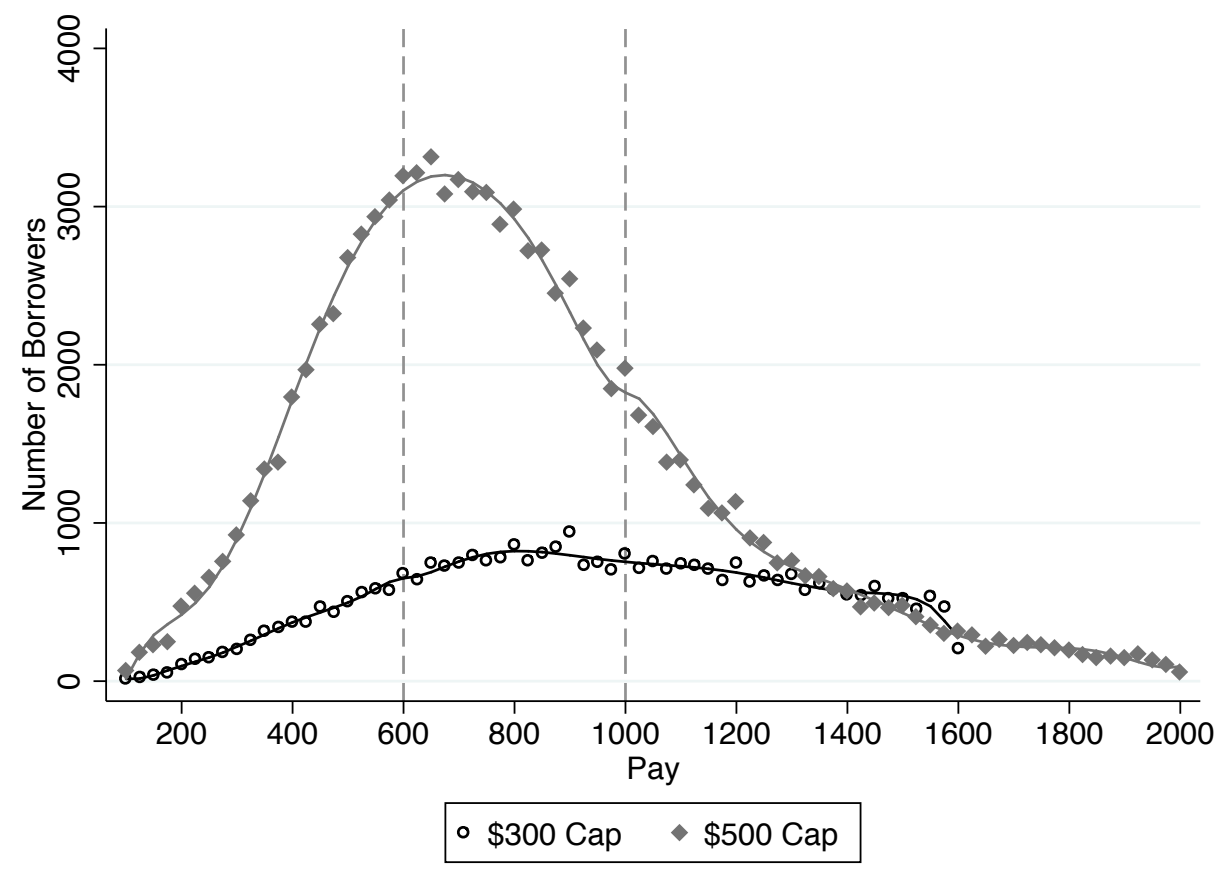

Notes: This figure plots the number of borrowers and biweekly pay for first-time payday borrowers in our regression kink sample. The sample consists of borrowers living in states offering payday loans in $\$ 1$ or $\$ 10$ increments who are paid biweekly or semimonthly and earning more than $\$ 100$ and within $\$ 1000$ of a kink point. The smoothed line controls for a seventh-order polynomial in pay interacted with being eligible for the maximum loan size in a state. See text for additional details. 
Online Appendix Figure 3

\section{Regression Discontinuity Falsification Test of First Stage}

A. Polynomial

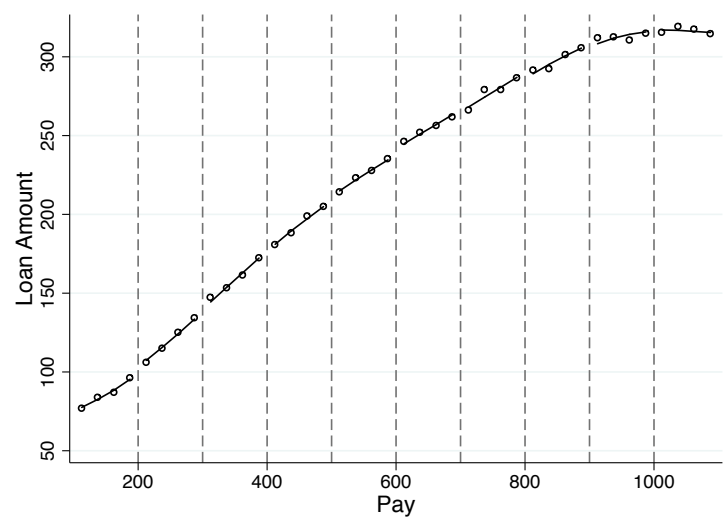

B. Linear Spline

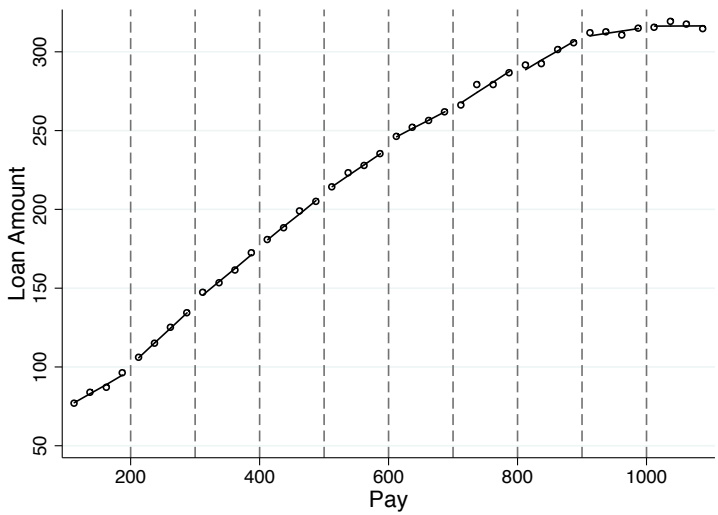

C. Local Lineaer

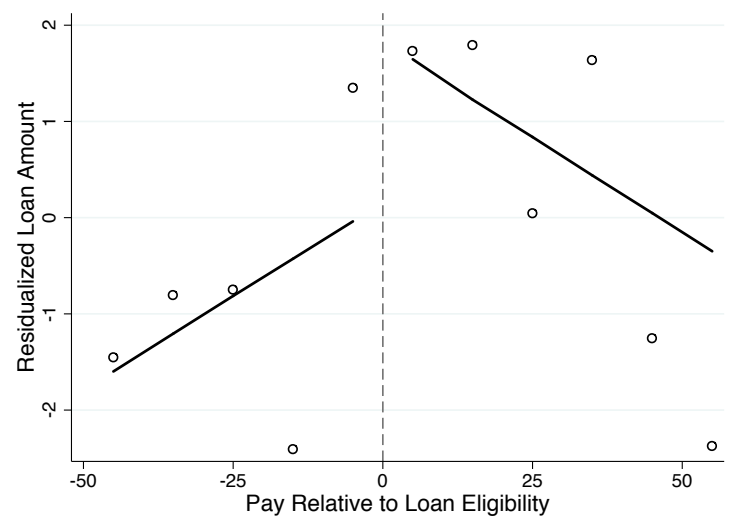

Notes: These figures plot average loan size and biweekly pay for first-time payday borrowers in a sample of states where no effect is expected. The sample consists of borrowers living in states offering payday loans in $\$ 1$ or $\$ 10$ increments who are paid biweekly or semimonthly between $\$ 100$ and $\$ 1100$. The smoothed line in Figure A controls for a seventh-order polynomial in net pay. Figure B controls for a linear spline in net pay. Figure $\mathrm{C}$ stacks data from each cutoff and controls for net pay using a linear regression and a linear regression interacted with the loan cutoff. See text for additional details. 
Online Appendix Figure 4

\section{Regression Discontinuity Falsification Test of Main Results}

A. Polynomial

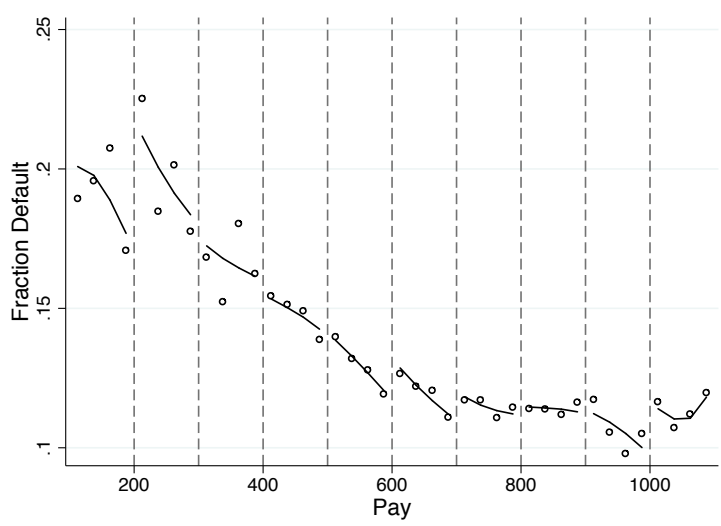

B. Linear Spline

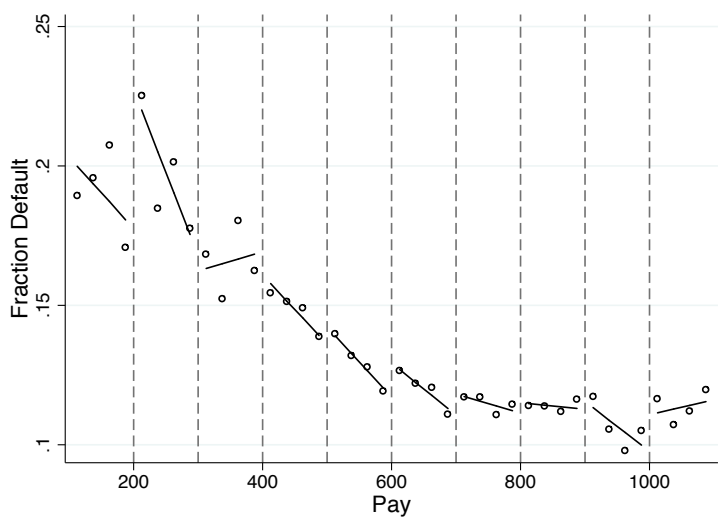

C. Local Linear

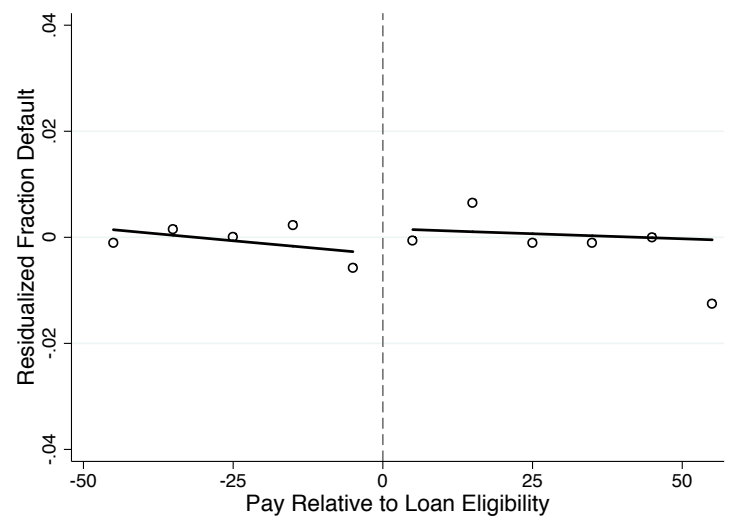

Notes: These figures plot average default and biweekly pay for first-time payday borrowers in a sample of states where no effect is expected. The sample consists of borrowers living in states offering payday loans in $\$ 1$ or $\$ 10$ increments who are paid biweekly or semimonthly between $\$ 100$ and $\$ 1100$. The smoothed line in Figure A controls for a seventh-order polynomial in net pay. Figure B controls for a linear spline in net pay. Figure $\mathrm{C}$ stacks data from each cutoff and controls for net pay using a linear regression and a linear regression interacted with the loan cutoff. See text for additional details. 